Published in final edited form as:

Oral Surg Oral Med Oral Pathol Oral Radiol Endod. 2011 September ; 112(3): e31-e35. doi:10.1016/ j.tripleo.2011.04.007.

\title{
Antiviral Effects of Blackberry Extract Against Herpes Simplex Virus Type 1
}

\author{
Robert J. Danaher, $\mathrm{PhD}^{1}$, Chunmei Wang, $\mathrm{MS}^{1}$, Jin Dai, $\mathrm{PhD}^{2}$, Russell J. Mumper, $\mathrm{PhD}^{2,3}$, \\ and Craig S. Miller, DMD., MS. ${ }^{1, *}$ \\ ${ }^{1}$ Department of Oral Health Practice, Center for Oral Health Research, College of Dentistry, \\ University of Kentucky, Lexington, KY \\ ${ }^{2}$ Four Tigers LLC, 1501 Bull Lea Road, Suite 105, Lexington, Kentucky 40511 \\ ${ }^{3}$ Division of Molecular Pharmaceutics, UNC Eshelman School of Pharmacy, University of North \\ Carolina at Chapel Hill, Chapel Hill, North Carolina, 27599-7355
}

\begin{abstract}
Objective-To evaluate antiviral properties of blackberry extract against herpes simplex virus type 1 (HSV-1) in vitro.

Methods-HSV-infected oral epithelial (OKF6) cells and cell-free virus suspensions were treated with blackberry extract $(2.24$ to $1400 \mu \mathrm{g} / \mathrm{mL})$ and virus yield and infectivity were quantified by direct plaque assay.

Results-Blackberry extract $\geq 56 \mu \mathrm{g} / \mathrm{ml}$ inhibited HSV-1 replication in oral epithelial cells by > $99 \%$ ( $\mathrm{p}<0.005$ ). Concentrations $\geq 280 \mu \mathrm{g} / \mathrm{ml}$ were antiviral when the extract was added after virus adsorption and entry. Exposure of cell-free virus to $\geq 280 \mu \mathrm{g} / \mathrm{ml}$ blackberry extract for 15 minutes at room temperature was virucidal $(\mathrm{p}=0.0002)$. The virucidal effects were not due to $\mathrm{pH}$ changes at concentrations up to $1500 \mu \mathrm{g} / \mathrm{ml}$.
\end{abstract}

Conclusions-Blackberry extract inhibited the early stages of HSV-1 replication and had potent virucidal activity. These properties suggest that this natural fruit extract could provide advantage as a topical prophylactic/therapeutic agent for HSV infections.

\section{Keywords}

herpes simplex virus; antiviral; blackberry extract

Herpes simplex virus (HSV) is an epitheliotropic virus that infects children and the majority of adults. ${ }^{1,2}$ Infection of epithelial cells (i.e., mucosa and skin) results in de-envelopment, rapid replication and spread to adjacent cells and nerve cell endings. Uptake of virions by nerve endings permits the virus to travel retroaxonally to the nerve cell bodies within the trigeminal ganglion, whereupon a quiescent state is established. ${ }^{3,4}$ HSV DNA resides longterm within the neuronal nuclei in a state that permits periodic reactivation and

(C) 2011 Mosby, Inc. All rights reserved.

"Corresponding author mailing address: Dr. Craig S. Miller, 800 Rose Street, MN324 Oral Medicine, College of Dentistry, University of Kentucky Medical Center, Lexington, KY 40536-0297. Phone: (859)-323-5950. Fax number: (859)-323-9136. cmiller@uky.edu.

Publisher's Disclaimer: This is a PDF file of an unedited manuscript that has been accepted for publication. As a service to our customers we are providing this early version of the manuscript. The manuscript will undergo copyediting, typesetting, and review of the resulting proof before it is published in its final citable form. Please note that during the production process errors may be discovered which could affect the content, and all legal disclaimers that apply to the journal pertain. 
recrudescence of progeny virus..$^{5,6}$ The ability of the virus to hide within relatively immune privilege sites makes elimination of this virus difficult.

Therapeutic options for HSV infections include the use of topical or systemic antiviral agents. ${ }^{7-11}$ Topical agents have the potential advantages of direct contact and disruption of various aspects of the virus life cycle, however most commercially available topical agents do not penetrate effectively and thus have been shown to only have minor benefit in limiting lesion eruption and duration. ${ }^{11-14}$ Also, topical antivirals can be expensive to use, especially since they often require frequent and recurrent applications. As an alternative, naturally occurring antiviral biochemicals found in plants and fruits could be less costly and more efficacious to use. To date, extracts from seeds, plants, roots and fruits have been shown to have antiviral activities. ${ }^{15-21}$ Of note, a large number of small molecules, like phenolics, polyphenols, and flavonoids found in fruits have been reported to be active anti-herpetic agents. ${ }^{16}$

Previously, our lab has shown that blackberries, which are rich in phenolics, polyphenols, and flavonoids have antioxidant, anti-inflammatory and antiproliferative properties. ${ }^{22,23}$ However, to our knowledge, scientific studies on the antiviral properties of blackberry extract have not been reported. In as much as HSV infections remain a global healthcare issue, we sought to investigate the antiviral effects of the extract against this well recognized viral pathogen.

\section{Methods}

\section{Cell culture and virus infectivity assays}

The immortalized keratinocyte cell line OKF6/hTERT-2 (OKF6), established by ectopic expression of the telomerase catalytic subunit (hTERT) in cells from normal oral mucosal epithelium, was obtained from Dr. James Rheinwald, Harvard Medical School. ${ }^{24}$ Vero cells were obtained from American Type Culture Collection (Rockville, Md). Cells were plated in 6-well tissue culture dishes at 3.75 and $6.25 \times 10^{5}$ cells/well, respectively, in Ker-SFM media and incubated at $37^{\circ} \mathrm{C}$ in a humidified incubator with $5 \% \mathrm{CO}_{2}$. The following day cells were inoculated with HSV-1 strain $17^{+}$, obtained from N. Fraser of the Wistar Institute, Philadelphia, at a multiplicity of infection (MOI) of $\leq 0.05$ and incubated at $37^{\circ} \mathrm{C}$ for $1 \mathrm{hr}$. Following two rinses with phosphate buffered saline (PBS), fresh media was added and incubation at $37^{\circ} \mathrm{C}$ was continued overnight. Twenty four hours post-inoculation, virus was released by three freeze thaw cycles and virus yield was determined in duplicate by direct plaque assay on Vero cell monolayers as we have previously described. ${ }^{25}$ In the viral replication inhibitory assays, triplicate cultures were supplemented with blackberry extract at the times (during adsorption, after removal of virus inoculums or throughout) and concentrations indicated. In the virucidal assays, cell-free virus suspensions $(25,000-$ 50,000 plaque forming units $[\mathrm{PFU}] / \mathrm{ml}$ ) were incubated with blackberry extract at $37^{\circ} \mathrm{C}$ for 1 hr or room temperature for 15 minutes. Virucidal assays were terminated at the indicated times by dilution of reaction mixture to non-antiviral levels of blackberry extract (1:100 culture media). Virus infectivity was determined by the direct plaque assay and is presented as the number of remaining PFUs relative to control treated virus suspensions.

Blackberry extract preparation-Hull blackberries (Rubus eubatus cv. "Hull") were grown at WindStone Farms (Paris, Kentucky). Seeds and skin were removed using a Langsenkamp type 161 Colossal Pulper and the resultant puree was stored at $-20^{\circ} \mathrm{C}$. Ethanol extracts were obtained from the puree. ${ }^{22}$ Briefly, blackberry puree $(10 \mathrm{~g})$ was treated under sonication for $30 \mathrm{~min}$ with $25 \mathrm{~mL}$ of extraction solvent of ethanol containing $0.01 \% \mathrm{HCl}$ (v/ v). The supernatants were collected after filtration and dried by rotary evaporation at $40^{\circ} \mathrm{C}$. The dried extract was resuspended in deionized water and filtered through a 20-25 $\mu \mathrm{m}$ filter 
paper and lyophilized to obtain dried ethanol extracts. Dried extracts was then redissolved in deionized water as a stock solution $(140 \mathrm{mg} / \mathrm{mL}, \mathrm{pH} 1.9-2.0)$ and stored at $-80^{\circ} \mathrm{C}$ until use.

\section{Results}

\section{Blackberry extract has anti-HSV-1 properties}

To determine if blackberry extract has antiviral properties, its ability to inhibit the HSV-1 replication cycle in oral epithelial cells was evaluated. To broadly evaluate possible antiviral activities cultures were maintained in the presence of increasing concentrations of blackberry extract $(0,2.24,11.2,56,280$ and $1400 \mu \mathrm{g} / \mathrm{ml})$ throughout the entire replication cycle (i.e. adsorption, entry and production of progeny). As shown in Figure 1, blackberry extract at $56 \mu \mathrm{g} / \mathrm{ml}$ significantly reduced HSV-1 yield by more than $99 \%(\mathrm{p}=0.004)$ and progeny virus was not detectable in cultures treated with extract at concentrations $\geq 280 \mu \mathrm{g} /$ $\mathrm{ml}$.

\section{Higher concentrations are required for antiviral effects when blackberry extract is added after HSV-1 entry}

OKF6 cells were inoculated with virus (MOI of 0.05 ), incubated at $37^{\circ} \mathrm{C}$ for $1 \mathrm{hr}$ and rinsed $2 \mathrm{X}$ with PBS prior to the addition of media supplemented with indicated concentration of blackberry extract. Virus yield was assessed $24 \mathrm{hr}$ post inoculation by titration on Vero cells following 3 freeze-thaw cycles. Although $56 \mu \mathrm{g} / \mathrm{ml}$ blackberry extract dramatically reduced virus yield when present throughout the entire replication cycle (Fig. 1), significant reductions in virus yield when provided after the $1 \mathrm{hr}$ adsorption and entry stage required concentrations $>280 \mu \mathrm{g} / \mathrm{ml}$ (Fig. 2). Similar results were obtained in experiments where Vero cells were infected with HSV-1 then exposed to blackberry extract (data not shown).

\section{Incubation with blackberry extract for $1 \mathrm{hr}$ at $37^{\circ} \mathrm{C}$ inactivates HSV-1}

The fact that blackberry extract at concentrations $\geq 56 \mu \mathrm{g} / \mathrm{ml}$ ) greatly reduced virus yield (> 99\%) when present throughout the inoculation and replication period but had no effect on yield at concentrations $\leq 280 \mathrm{ng} / \mathrm{ml}$ when added following virus entry (Fig. 2) indicated that blackberry extract may either inactivate the virus directly or block virus entry. To determine in blackberry extract inactivates HSV-1, the extract was added to cell-free virus suspensions, at the indicated concentrations, and incubated at $37^{\circ} \mathrm{C}$ for $1 \mathrm{hr}$ to mimic the adsorption and entry phase. Blackberry extract treated virus suspensions were diluted beyond the antiviral concentration $(1: 100)$ with culture media and then virus infectivity was quantified by direct plaque assay. In these experiments, even at the highest concentrations used the extract did not affect the number of viable epithelial cells (data not shown). As indicated in Figure 3, the amount of infectious HSV-1 virus remaining after $1 \mathrm{hr}$ incubation at $37^{\circ} \mathrm{C}$ with $280 \mu \mathrm{g} /$ $\mathrm{ml}$ blackberry extract was significantly reduced compared to control cultures. Taken together, these findings indicate a dose dependent antiviral effect of blackberry extract and that this effect was most pronounced at the level of inactivation of cell-free virus.

\section{Short-term incubation with blackberry extract at room temperature inactivates HSV-1}

To further evaluate the effectiveness of blackberry extract on virus infectivity, HSV-1 suspensions were incubated with the indicated concentration of extract at room temperature for 15 minutes to simulate intraoral use. HSV-1 infectivity was determined by direct plaque assay on Vero cell monolayers. Similar to above, exposure of cell-free virus to $\geq 280 \mu \mathrm{g} / \mathrm{ml}$ blackberry extract for as little as 15 minutes significantly reduced HSV-1 infectivity (Fig. 4). Here higher concentrations of blackberry extract were required with $\geq 560 \mu \mathrm{g} / \mathrm{ml}$ blackberry extract eliminating at least $50 \%$ of infectious virus and concentrations $\geq 1500 \mu \mathrm{g} / \mathrm{ml}$ blackberry extract reducing $>90 \%$ of infectious virus. In as much as acidic $\mathrm{pH}$ is known to 
alter the infectivity of HSV-1, we quantified the $\mathrm{pH}$ of all the concentrations tested. Here the diluted extract remained within neutral $\mathrm{pH}$ (i.e., > 6.8), suggesting that the antiviral effect was more likely associated with the natural constituents within the blackberry extract than $\mathrm{pH}$.

\section{Discussion}

Blackberries are a natural and abundant fruit that grow in the wild and as cultivars. As early as the $16^{\text {th }}$ century, blackberry juice was used to treat infections of the mouth and eyes. The extract, juice and leaves of blackberries are rich in polyphenols, which have antiinflammatory and antibacterial properties. ${ }^{23,} 26$ Here we further extended studies of blackberry extract by investigating its antiviral properties and mechanism of action. These studies add to the growing body of evidence that blackberry extract may provide benefit to a large percentage of the world's population by targeting a well recognized viral pathogen.

In the viral inhibition studies performed with blackberry extract we found that there was near total inhibition of growth of HSV-1 in vitro at concentrations of $>56 \mu \mathrm{g} / \mathrm{ml}$. The antiviral effects were most noticeable when free virus was directly exposed to the blackberry extract (i.e., before the infection), and less effective once HSV-1 had adsorbed and entered epithelial cells (i.e., either OKF6 or Vero cells). This indicates that the extract has strong antiviral effects that interfere with adsorption or entry into host cells and some intracellular activity. While the minimum inhibitory concentrations were defined, it remains to be determined whether the main inhibitory effect is due to impairment of viral proteins involved in host cell receptor binding, adsorption and/or penetration of virions.

Polyphenols derived from plants have been shown to have antiviral activity (reviewed in $^{16,27}$ ). Specifically, the flavonoids galangin, quercetin, procyanidin and pelargonidin as well as procyanidin C-1 are found to be virucidal against HSV. ${ }^{21,28-30}$ The antiviral effect of these substances is greatest when used before virus adsorption ${ }^{30-32}$ which is consistent with our findings. Blackberries are known to contain high amount of anthocyanins and ellagitannins, thus those polyphenols in blackberry extract are likely individual or synergist contributors to the antiviral effects observed.

In summary, our findings suggest that blackberry extract with its viral replication inhibitory and rapid virucidal activities could be an effective topical treatment and/or prophylactic agent for oral herpetic infections. These findings set the stage for future studies that would isolate and identify the bioactive anti-HSV molecules in blackberry extract, and determine whether the bioactive principle(s) in blackberry extract exhibit antiviral effects against additional HSV strains and serotypes (i.e., HSV-2) in preclinical and toxicity evaluations.

\section{Acknowledgments}

The project described was supported by Award Number R41DE018839 from the National Institute of Dental \& Craniofacial Research to CSM, RJD, JD, and RJM. The content is solely the responsibility of the authors and does not necessarily represent the official views of the National Institute of Dental \& Craniofacial Research or the National Institutes of Health.

\section{References}

1. Bader C, Crumpacker CS, Schnipper LE, Ransil B, Clark JE, Arndt K, et al. The natural history of recurrent facial-oral infection with herpes simplex virus. J Infect Dis. 1978; 138(6):897-905. [PubMed: 216753]

2. Smith JS, Robinson NJ. Age-specific prevalence of infection with herpes simplex virus types 2 and 1: a global review. J Infect Dis. 2002; 186 (Suppl 1):S3-28. [PubMed: 12353183] 
3. Stevens JG, Cook ML. Latent herpes simplex virus in spinal ganglia of mice. Science. 1971; 173:843-45. [PubMed: 4328483]

4. Stevens JG. Latent herpes simplex virus and the nervous system. Curr Top Microbiol Immunol. 1975; 70:31-50. [PubMed: 169103]

5. Kaufman HE, Brown DC, Ellison EM. Recurrent herpes in the rabbit and man. Science. 1967; 156(3782):1628-9. [PubMed: 4290539]

6. Lachmann R. Herpes simplex virus latency. Expert Rev Mol Med. 2003; 5(29):1-14. [PubMed: 14987404]

7. Spruance SL, Crumpacker CS, Schnipper LE, Kern ER, Marlowe S, Arndt KA, et al. Early, patientinitiated treatment of herpes labialis with topical $10 \%$ acyclovir. Antimicrob Agents Chemother. 1984; 25(5):553-5. [PubMed: 6732224]

8. Spruance SL, Nett R, Marbury T, Wolff R, Johnson J, Spaulding T. Acyclovir cream for treatment of herpes simplex labialis: results of two randomized, double-blind, vehicle-controlled, multicenter clinical trials. Antimicrob Agents Chemother. 2002; 46(7):2238-43. [PubMed: 12069980]

9. Spruance SL, Rea TL, Thoming C, Tucker R, Saltzman R, Boon R. Penciclovir cream for the treatment of herpes simplex labialis. A randomized, multicenter, double-blind, placebo-controlled trial. Topical Penciclovir Collaborative Study Group. JAMA. 1997; 277(17):1374-9. [PubMed: 9134943]

10. Scully C. Orofacial herpes simplex virus infections: current concepts in the epidemiology, pathogenesis, and treatment, and disorders in which the virus may be implicated. Oral Surg Oral Med Oral Pathol. 1989; 68(6):701-10. [PubMed: 2556674]

11. Woo SB, Challacombe SJ. Management of recurrent oral herpes simplex infections. Oral Surg Oral Med Oral Pathol Oral Radiol Endod. 2007; 103(Suppl):S12, e1-18. [PubMed: 17379150]

12. Freeman DJ, Sheth NV, Spruance SL. Failure of topical acyclovir in ointment to penetrate human skin. Antimicrob Agents Chemother. 1986; 29(5):730-2. [PubMed: 3729337]

13. Raborn GW, McGaw WT, Grace M, Percy J. Treatment of herpes labialis with acyclovir. Review of three clinical trials. Am J Med. 1988; 85(2A):39-42. [PubMed: 3044091]

14. Raborn GW, McGaw WT, Grace M, Houle L. Herpes labialis treatment with acyclovir 5 per cent ointment. J Can Dent Assoc. 1989; 55(2):135-7. [PubMed: 2645030]

15. Kanekiyo K, Hayashi K, Lee JB, Takenaka H, Hayashi T. Structure and antiviral activity of an acidic polysaccharide from an edible blue-green alga, Nostoc flagelliforme. Yakugaku Zasshi. 2008; 128(5):725-31. [PubMed: 18451619]

16. Khan MT, Ather A, Thompson KD, Gambari R. Extracts and molecules from medicinal plants against herpes simplex viruses. Antiviral Res. 2005; 67(2):107-19. [PubMed: 16040137]

17. Elanchezhiyan M, Rajarajan S, Rajendran P, Subramanian S, Thyagarajan SP. Antiviral properties of the seed extract of an Indian medicinal plant, Pongamia pinnata, Linn. against herpes simplex viruses: in-vitro studies on Vero cells. J Med Microbiol. 1993; 38(4):262-4. [PubMed: 8386251]

18. Kott V, Barbini L, Cruanes M, Munoz JD, Vivot E, Cruanes J, et al. Antiviral activity in Argentine medicinal plants. J Ethnopharmacol. 1999; 64(1):79-84. [PubMed: 10075125]

19. Pedraza-Chaverri J, Cardenas-Rodriguez N, Orozco-Ibarra M, Perez-Rojas JM. Medicinal properties of mangosteen (Garcinia mangostana). Food Chem Toxicol. 2008; 46(10):3227-39. [PubMed: 18725264]

20. Lopez A, Hudson JB, Towers GH. Antiviral and antimicrobial activities of Colombian medicinal plants. J Ethnopharmacol. 2001; 77(2-3):189-96. [PubMed: 11535363]

21. Meyer JJ, Afolayan AJ, Taylor MB, Erasmus D. Antiviral activity of galangin isolated from the aerial parts of Helichrysum aureonitens. J Ethnopharmacol. 1997; 56(2):165-9. [PubMed: 9174978]

22. Dai J, Patel JD, Mumper RJ. Characterization of blackberry extract and its antiproliferative and anti-inflammatory properties. J Med Food. 2007; 10(2):258-65. [PubMed: 17651061]

23. Dai J, Mumper RJ. Plant phenolics: extraction, analysis and their antioxidant and anticancer properties. Molecules. 2010; 15(10):7313-52. [PubMed: 20966876]

24. Dickson MA, Hahn WC, Ino Y, Ronfard V, Wu JY, Weinberg RA, et al. Human keratinocytes that express hTERT and also bypass a p16(INK4a)-enforced mechanism that limits life span become 
immortal yet retain normal growth and differentiation characteristics. Mol Cell Biol. 2000; 20(4): 1436-47. [PubMed: 10648628]

25. Miller CS, Smith KO. Enhanced replication of herpes simplex virus type 1 in human cells. J Dent Res. 1991; 70(2):111-7. [PubMed: 1846885]

26. Martini S, D'Addario C, Colacevich A, Focardi S, Borghini F, Santucci A, et al. Antimicrobial activity against Helicobacter pylori strains and antioxidant properties of blackberry leaves (Rubus ulmifolius) and isolated compounds. Int J Antimicrob Agents. 2009; 34(1):50-9. [PubMed: 19386474]

27. Cushnie TP, Lamb AJ. Antimicrobial activity of flavonoids. Int J Antimicrob Agents. 2005; 26(5): 343-56. [PubMed: 16323269]

28. Amoros M, Simoes CM, Girre L, Sauvager F, Cormier M. Synergistic effect of flavones and flavonols against herpes simplex virus type 1 in cell culture. Comparison with the antiviral activity of propolis. J Nat Prod. 1992; 55(12):1732-40. [PubMed: 1338212]

29. Debiaggi M, Tateo F, Pagani L, Luini M, Romero E. Effects of propolis flavonoids on virus infectivity and replication. Microbiologica. 1990; 13(3):207-13. [PubMed: 2125682]

30. Shahat AA, Cos P, De Bruyne T, Apers S, Hammouda FM, Ismail SI, et al. Antiviral and antioxidant activity of flavonoids and proanthocyanidins from Crataegus sinaica. Planta Med. 2002; 68(6):539-41. [PubMed: 12094299]

31. Schnitzler P, Neuner A, Nolkemper S, Zundel C, Nowack H, Sensch KH, et al. Antiviral activity and mode of action of propolis extracts and selected compounds. Phytother Res. 24(Suppl 1):S208. [PubMed: 19472427]

32. Lyu SY, Rhim JY, Park WB. Antiherpetic activities of flavonoids against herpes simplex virus type 1 (HSV-1) and type 2 (HSV-2) in vitro. Arch Pharm Res. 2005; 28(11):1293-301. [PubMed: 16350858] 


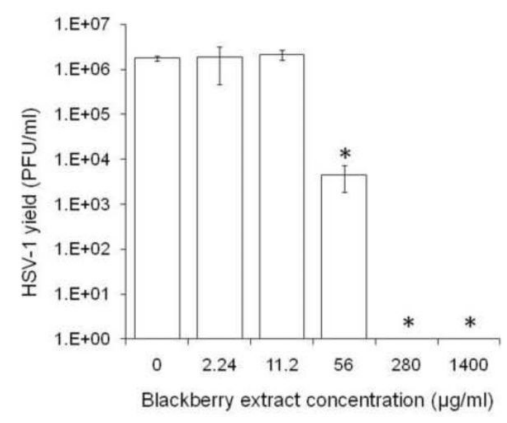

Figure 1. Blackberry Extract has antiviral properties

Oral epithelial cells were inoculated with HSV-1 strain $17^{+}(\mathrm{MOI}=0.05)$ in the presence of the indicated concentration of blackberry extract. Following cell adsorption at $37^{\circ} \mathrm{C}$ and two rinses with PBS, fresh cell culture media containing the indicated concentration of blackberry extract was added and incubation was continued overnight at $37^{\circ} \mathrm{C}$. Twenty four hours post inoculation, cells were freeze-thawed 3 times and virus yield was quantified on Vero cell monolayers by the direct plaque assay. Data represents the average +/- SD of triplicate replication assays (i.e. $\mathrm{n}=3$ ). ${ }^{*}, \mathrm{p}<0.005$. 


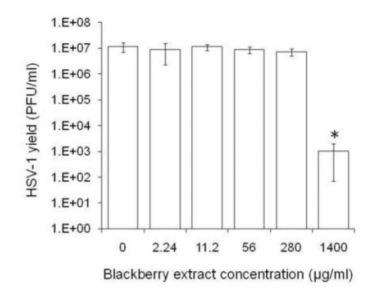

Figure 2. Cell entry protects HSV-1 from antiviral effects of blackberry extract

HSV-1 strain $17^{+}$was added to oral epithelial cells at an MOI $=0.05$ and allowed to adsorb and enter for $1 \mathrm{hr}$ at $37^{\circ} \mathrm{C}$. Fresh cell culture media, containing the indicated concentration of blackberry extract, was added and incubation was continued overnight, followed by two PBS rinses. Twenty four hours post inoculation, cells were freeze-thawed 3 times and virus yield was quantified on Vero cell monolayers by the direct plaque assay. Data represents the average $+/-\mathrm{SD}$ of triplicate replication assays (i.e. $\mathrm{n}=3$ ). ${ }^{*}, \mathrm{p}<0.005$. 


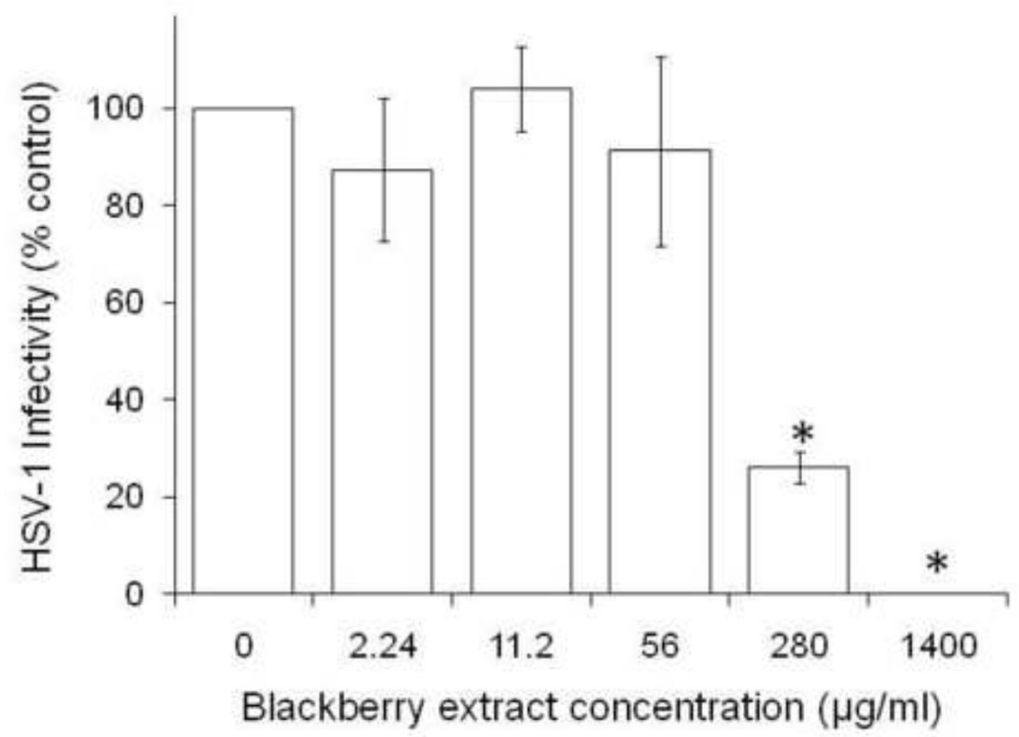

Figure 3. BBE inactivates HSV-1

Cell-free suspensions of HSV-1 (Strain $17^{+}$) were incubated at $37^{\circ} \mathrm{C}$ for $1 \mathrm{hr}$ with the indicated concentration of BBE. Infections virus was quantified by the direct plaque assay in triplicate. Results are the average of two independent experiments $(n=2)$ and are presented relative to untreated controls $(100 \%){ }^{*}, \mathrm{p}<0.005$. 


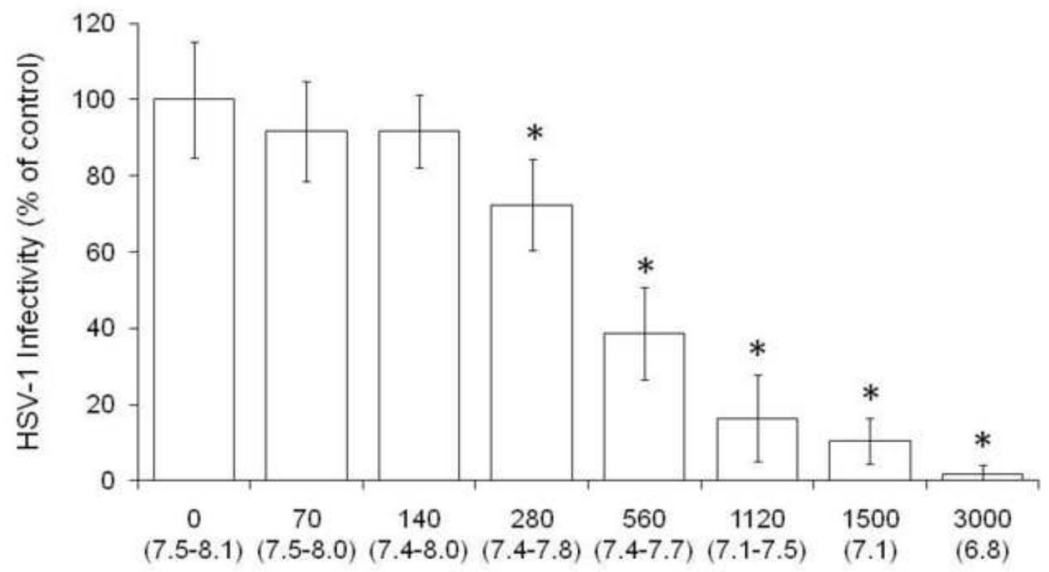

Blackberry extract concentration in $\mu \mathrm{g} / \mathrm{ml}$ ( $\mathrm{pH}$ range)

Figure 4. BBE inactivates HSV-1

Cell-free suspensions of HSV-1 (Strain $17^{+}$) were incubated at room temperature for 15 minutes with the indicated concentration of BBE. Infectious virus was quantified by the direct plaque assay in triplicate. Results are the average of two independent experiments in duplicate $(n=4)$ and are presented relative to untreated controls $(100 \%)$ *, p $<0.005$. 